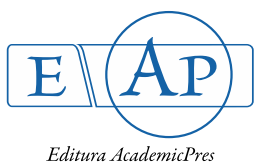

\title{
Exogenous Salicylic Acid Mediated Physiological Responses and Improvement in Yield by Modulating Antioxidant Defense System of Wheat under Salinity
}

\section{Janatul FARDUS ${ }^{1}$, Md. Abdul MATIN ${ }^{1}$, Md. HASANUZZAMAN ${ }^{1}$, Md. Shahadat HOSSAIN ${ }^{2}$, Sheymol Dev NATH ${ }^{1}$, Md. Amzad HOSSAIN ${ }^{3}, \mathrm{Md}$. Motiar ROHMAN ${ }^{4}$, Mirza HASANUZZAMAN ${ }^{1 *}$}

\author{
'Sher-e-Bangla Agricultural University, Faculty of Agriculture, Department of Agronomy, \\ Dhaka-1207,Bangladesh;mbzsauag@yahoo.com (*orresponding author) \\ ${ }^{2}$ Sher-e-Bangla Agricultural University, Faculty of Agriculture, Department of Biotechnology, Dhaka-1207, Bangladesh \\ ${ }^{3}$ University of the Ryukyus, Faculty of Agriculture, Subtropical Field Science Center, 1 Senbaru, Nishihara, Okinawa, Japan \\ ${ }^{4}$ Bangladesh Agricultural Research Institute, Plant Breeding Division, Molecular Breeding Laboratory, Joydebpur, Gazipur-1701, Bangladesh
}

\begin{abstract}
The present study investigated the regulatory roles of exogenous salicylic acid (SA) in physiology, antioxidant defense systems and yield of wheat under different salt stress conditions. The experiment was conducted with two varieties, 'BARI Gom 21' and 'BARI Gom 25' and ten salt stress treatments viz. control (without salt), SA (1 mM salicylic acid), S50 (50 mM $\mathrm{NaCl}$ ), S50+SA ( $50 \mathrm{mM} \mathrm{NaCl}$ with $1 \mathrm{mM} \mathrm{SA}), S 100(100 \mathrm{mM} \mathrm{NaCl})$, S100+SA (100 mM NaCl with $1 \mathrm{mM} \mathrm{SA}), S 150$ (150 $\mathrm{mM} \mathrm{NaCl}), S 150+\mathrm{SA}(150 \mathrm{mM} \mathrm{NaCl}$ with $1 \mathrm{mM} \mathrm{SA}), \mathrm{S} 200(200 \mathrm{mM} \mathrm{NaCl})$ and S200+SA (200 mM NaCl with $1 \mathrm{mM} \mathrm{SA})$. Leaf relative water content (RWC) and chlorophyll (chl) content reduced due to salt stress. The malondialdelyde (MDA) and $\mathrm{H}_{2} \mathrm{O}_{2}$ were increased under the stress condition. The ascorbate (AsA) content, reduced glutathione (GSH) and GSH/GSSG ratio were reduced by salt stresses $(50,100,150$ and $200 \mathrm{mM} \mathrm{NaCl}$, respectively). But the glutathione disulfide (GSSG) amount increased with an increase in the all levels of salinity. The ascorbate peroxidase (APX), monodehydroascorbate reductase (MDHAR), dehydroascorbate reductase (DHAR) and catalase (CAT) activities showed a significant reduction in response to salt stress, but CAT increased only at $100 \mathrm{mM}$ stress condition. The glutathione $S$-transferase (GST) and glutathione reductase (GR) activity increased significantly with severe salt stress $(200 \mathrm{mM} \mathrm{NaCl})$. Also the activity of peroxidase (POD) was decreased with increasing salinity level. At harvest, salt stresses reduced the effective tiller hill ${ }^{-1}, 1,000$ grain weight, grain yield, straw yield, biological yield and harvest index for both of varieties. However, the number of noneffective tiller hill ${ }^{-1}$ significantly increased in response of salt stress. Exogenous $1 \mathrm{mM} \mathrm{SA}$ application with salt stress improved physiological parameters, yield and reduced oxidative damage in both cultivars, where 'BARI Gom 25' showed better tolerance. SA application could not improve physiological parameters and yield at extreme level of salt stress $(200 \mathrm{mM} \mathrm{NaCl})$.
\end{abstract}

Keywords: abiotic stress, antioxidant defense, oxidative stress, phytohormone, reactive oxygen species

\section{Introduction}

Different abiotic stresses like salinity, drought, extreme temperatures, metal toxicity, flooding, UV-B radiation, ozone, etc. hamper plant growth, metabolism and productivity, as crop plants are sessile organisms (Hasanuzzaman et al., 2012a, b; 2013; 2014). Among the abiotic stresses, salt stress is a major environmental threat to agriculture, and its adverse impacts are getting more serious problems in regions where saline water is used for irrigation
(Türkan and Demiral, 2009). More than 30\% of the total agricultural production in world comes from around $17 \%$ of the cultivable land which is under irrigation and irrigated agriculture (Hillel, 2000). It is estimated that at least $20 \%$ of total irrigated lands in the world is salt-affected (Pitman and Läuchli, 2002; Munns and Tester, 2008). In most of the cases, the negative effects of salinity have been attributed to increase in $\mathrm{Na}+$ and $\mathrm{Cl}$ - ions in different plants hence these ions produce the critical conditions for plant survival by intercepting different plant mechanisms. Although both $\mathrm{Na}+$ and $\mathrm{Cl}$ - are the major ions produce many physiological 
220

disorders in plant, $\mathrm{Cl}$ - is the most dangerous (Tavakkoli et al., 2010). Salinity at higher levels causes both hyperionic and hyperosmotic stress and can lead to plant demise. The outcome of these effects may cause membrane damage, nutrient imbalance, altered levels of growth regulators, enzymatic inhibition and metabolic dysfunction, including photosynthesis which ultimately leading to plant death (Mahajan and Tuteja, 2005; Hasanuzzaman et al., 2012a). Molecular and biochemical studies of the salt stress responses of plants have demonstrated significant increases in reactive oxygen species (ROS) such as, singlet oxygen (1O2), superoxide (O2.-), hydrogen peroxide ( $\mathrm{H} 2 \mathrm{O} 2)$, and hydroxyl radical (OH) (Mittler, 2002; Tanou et al., 2009; Pérez-López et al., 2010). In general, plant cells are adequately equipped to keep ROS within the limits that are generated as a consequence of normal cellular metabolic activities. Under different stress conditions, ROS generation often exceeds the overall cellular antioxidative potential leading to stress-induced adverse effects on plant growth and physiology. A steady state balanced is required to protect plant cells from oxidative damage (Hasanuzzaman et al., 2011). Plants possess an efficient non-enzymatic (AsA, GSH, $\alpha$-tocopherol, phenolic compounds, alkaloids and non-protein amino acids) and enzymatic (SOD, CAT, APX, MDHAR, DHAR, GR, GPX, GST and POD) antioxidant defense systems which work in concert to control the cascades of uncontrolled oxidation and protect plant cells from oxidative damage by scavenging ROS (Gill and Tuteja, 2010). These antioxidant defense systems are found in almost all cellular compartments, demonstrating the importance of ROS detoxification for cellular survival (Gill and Tuteja, 2010). Therefore, efforts to increase the salt tolerance of crop plants are very important to ensure global food security, as well as for water and land conservation. Now, is the right time to be strategic: first by understanding the reasons fundamental to complex - for yield reductions so that precise research planning can be brought about to cope with increasing salinity problems. With that view, plant scientists are now searching for ways to make the plants adaptive under saline conditions. Researchers are trying to understand the effects of salt stress on plants so that they can modify the plant's external growing condition as well as change the plant from within by applying different exogenous protectants including trace elements and phytohormones by molecular mechanisms. Salicylic acid (SA) is a common plant-produced phenolic compound and a potential endogenous plant hormone that plays an important role in plant growth and development (Hasanuzzaman et al., 2014). The role of SA is intensively studied in plant responses to biotic stress. In recent years, the involvement of $S A$ in the response to abiotic stresses has come into light. Several studies support a major role of SA in plant adaptation to the changing environment, and induce plant tolerance to various abiotic stresses including elevated $\mathrm{NaCl}$ (Stevens et al., 2006; Arfan et al., 2007; Gunes et al., 2007). It is a well observed fact that SA potentially generates a wide array of metabolic responses in plants and also affects plant water relations (Hayat $e t$ al., 2010).

\section{Materials and Methods}

\section{Plant materials and stress treatments}

Seed of a salt tolerant ('BARI Gom 25') and salt sensitive ('BARI Gom 21') variety of wheat were collected from Bangladesh Agriculture Research Institute, Joydebpur, Gazipur, Bangladesh. A pot experiment was conducted at the experimental shed of the Department of Agronomy, Sher-e-Bangla Agricultural University, Dhaka $\left(90^{\circ} 77^{\prime}\right.$ E longitude and $23^{\circ} 77^{\prime} \mathrm{N}$ latitude) during the period of November 2013 to March 2014. Empty earthen pots with 18 inch depth were used for the experiment. Twelve kilogram sun-dried soils were put in each pot.

The soil and fertilizers were mixed well before placing the soils in the pots. Fertilizers used in the experimental pots were urea, triple super phosphate, muriate of potash and gypsum@ 4.6, 4.1, 2.7 and 1.2 g/pot. One-third of urea and the whole amount of other fertilizers were incorporated with soil at final pot preparation before sowing. Rest of the nitrogen were applied in two equal splits one at 30 days after sowing (DAS) and the other at 60 DAS. Fifteen healthy seeds of each variety were sown in each pot. After germination 9-10 plants were allowed to grow in each pot. There were five salinity levels including control where developed by adding respected amount commercial $\mathrm{NaCl}$ salt to the soil/pot as water dissolved solution. The salinity levels were C (control), S50 (50 mM NaCl), S100 (100 $\mathrm{mM} \mathrm{NaCl}), S 150(150 \mathrm{mM} \mathrm{NaCl})$ and $S 200(200 \mathrm{mM}$ $\mathrm{NaCl}$ ). The salinity treatments were applied on $28,35,42$, 49, 56 and 63 DAS (days after sowing). Salicylic acid (SA) was used as a protectants. The concentration of SA was $1 \mathrm{mM}$ and applied as spray solution under non-saline (SA) and saline (S50, S100, S150 and S200) condition. The experiment was laid out in a Randomized Completely Block Design (RCBD) with three replications.

\section{Measurement of relative water content (\%)}

Three leaves were randomly selected from each pot and $\mathrm{cu}$ with scissors. Relative water content (RWC) was measured according to Barrs and Weatherley (1962). Leaf laminas were weighed (Fresh weight, FW) and then immediately floated on distilled water in a petri dish for $4 \mathrm{~h}$ in the dark. Turgid weights (TW) were obtained after drying excess surface water with paper towels. Dry weights (DW) were measured after drying at $80^{\circ} \mathrm{C}$ for $48 \mathrm{~h}$. Then calculation was done using the following formula:

RWC $(\%)=($ FW-DW $) /($ TW-DW $) \times 100$.

\section{Determination of chlorophyll content}

Three leaves were randomly selected from each pot. The top and bottom of each leaf were measured with atLEAF as atLEAF value. Then it was averaged and total chlorophyll content was measured by the conversion of at LEAF value into SPAD units and then total chl content was measured.

\section{Measurement of lipidperoxidation}

The level of lipid peroxidation was measured by estimating MDA, a decomposition product of the peroxidized polyunsaturated fatty acid component of the membrane lipid, using thiobarbituric acid (TBA) as the 
reactive material following the method of Heath and Packer (1968) with slight modifications. The leaf samples $(0.5 \mathrm{~g})$ were homogenized in $3 \mathrm{ml} \mathrm{5 \%}$ (w/v) trichloroacetic acid (TCA) and the homogenate was centrifuged at $11,500 \times \mathrm{g}$ for $15 \mathrm{~min}$. One $\mathrm{ml}$ supernatant was mixed with $4 \mathrm{ml}$ of TBA reagent ( $0.5 \%$ of TBA in $20 \%$ TCA). The reaction mixture was heated at $95^{\circ} \mathrm{C}$ for $30 \mathrm{~min}$ in a water bath and then quickly cooled in an ice bath and centrifuged at $11,500 \times \mathrm{g}$ for $15 \mathrm{~min}$. The absorbance of the coloured supernatant was measured at $532 \mathrm{~nm}$ and was corrected for non-specific absorbance at $600 \mathrm{~nm}$. The concentration of MDA was calculated by using the extinction coefficient of $155 \mathrm{mM}-1 \mathrm{~cm}-1$ and expressed as nmol of MDA g-1 fresh weight.

\section{Measurement of $\mathrm{H}_{2} \mathrm{O}_{2}$}

$\mathrm{H}_{2} \mathrm{O}_{2}$ was assayed according to the method described by $\mathrm{Yu}$ et al. (2003). $\mathrm{H}_{2} \mathrm{O}_{2}$ was extracted by homogenizing $0.5 \mathrm{~g}$ of leaf samples with $3 \mathrm{ml}$ of $50 \mathrm{mM} \mathrm{K}$-phosphate buffer $\mathrm{pH}(6.5)$ at 4 ${ }^{\circ} \mathrm{C}$. The homogenate was centrifuged at $11,500 \times \mathrm{g}$ for $15 \mathrm{~min} .3$ $\mathrm{ml}$ of supernatant was mixed with $1 \mathrm{ml}$ of $0.1 \% \mathrm{TiCl}_{4}$ in $20 \%$ $\mathrm{H}_{2} \mathrm{SO}_{4}(\mathrm{v} / \mathrm{v})$, and the mixture was then centrifuged at $11,500 \mathrm{~g}$ for $12 \mathrm{~min}$ at room temperature. The optical absorption of the supernatant was measured spectrophotometrically at $410 \mathrm{~nm}$ to determine the $\mathrm{H}_{2} \mathrm{O}_{2}$ content $\left(\mathcal{E}=0.28 \mu \mathrm{M}^{-1} \mathrm{~cm}^{-1}\right)$ and expressed as $\mathrm{mol} \mathrm{g}^{-1}$ fresh weight.

\section{Extraction and measurement of ascorbate and glutathione}

Wheat leaves ( $0.5 \mathrm{~g}$ fresh weight) were homogenized in $3 \mathrm{~mL}$ ice-cold acidic extraction buffer (5\% metaphosphoric acid containing $1 \mathrm{mM}$ EDTA) using a mortar and pestle. Homogenates were centrifuged at $11,500 \times \mathrm{g}$ for $15 \mathrm{~min}$ at 4 ${ }^{\circ} \mathrm{C}$ and the supernatant was collected for analysis of ascorbate and glutathione.

Ascorbate content was determined following the method of Huang et al. (2005) with some modifications. The supernatant was neutralized with $0.5 \mathrm{M} \mathrm{K-P}$ buffer (pH 7.0). The AsA was assayed spectrophotometrically at $265 \mathrm{~nm}$ in $100 \mathrm{mM} \mathrm{KP}$ buffer $(\mathrm{pH} 7.0)$ with 0.5 unit of ascorbate oxidase (AO). A specific standard curve with AsA was used for quantification.

The glutathione pool was assayed according to previously described methods of Paradiso et al. (2008) with modifications utilizing 200 span style of aliquots of supernatant neutralized with 300 span style of $0.5 \mathrm{M} \mathrm{K-P}$ buffer ( $\mathrm{pH} 7.0)$. Based on enzymatic recycling, $\mathrm{GSH}$ is oxidized by $5,5^{\prime}$ - dithio- bis (2-nitrobenzoic acid) (DTNB) and reduced by NADPH in the presence of GR, and glutathione content is evaluated by the rate of absorption changes at $412 \mathrm{~nm}$ of 2-nitro-5-thiobenzoic acid (NTB) generated from the reduction of DTNB. GSSG was determined after removal of GSH by 2-vinylpyridine derivatization. Standard curves with known concentrations of GSH and GSSG were used. The content of GSH was calculated by subtracting GSSG from total GSH.

\section{Determination of protein}

The protein concentration of each sample was determined following the method of Bradford (1976) using BSA as a protein standard.

Enzyme extraction and assays
Using a pre-cooled mortar and pestle, $0.5 \mathrm{~g}$ of leaf tissue was homogenized in $1 \mathrm{ml}$ of $50 \mathrm{mM}$ ice-cold K-phosphate buffer ( $\mathrm{pH} 7.0)$ containing $100 \mathrm{mM} \mathrm{KCl,} 1 \mathrm{mM}$ ascorbate, $5 \mathrm{mM} \beta$-mercaptoethanol and $10 \%(\mathrm{w} / \mathrm{v})$ glycerol. The homogenates were centrifuged at $11,500 \times \mathrm{g}$ for $15 \mathrm{~min}$ and the supernatants were used for determination of enzyme activity. All procedures were performed at a temperature 0-4 ${ }^{\circ} \mathrm{C}$.

Ascorbate peroxidase (EC: 1.11.1.11) activity was assayed following the method of Nakano and Asada (1981). The reaction buffer solution contained $50 \mathrm{mM} \mathrm{K}$ phosphate buffer ( $\mathrm{pH} 7.0$ ), $0.5 \mathrm{mM}$ AsA, $0.1 \mathrm{mM} \mathrm{H} 2 \mathrm{O} 2$, $0.1 \mathrm{mM}$ EDTA, and enzyme extract in a final volume of $700 \mu \mathrm{L}$. The reaction was started by the addition of $\mathrm{H} 2 \mathrm{O} 2$ and the activity was measured by observing the decrease in absorbance at $290 \mathrm{~nm}$ for 1 min using an extinction coefficient of $2.8 \mathrm{mM}-1 \mathrm{~cm}-1$.

Monodehydroascorbate reductase (EC: 1.6.5.4) activity was determined by the method of Hossain et al. (1984). The reaction mixture contained $50 \mathrm{mM}$ Tris-HCl buffer ( $\mathrm{pH} 7.5), 0.2 \mathrm{mM}$ NADPH, $2.5 \mathrm{mM}$ AsA, and 0.5 unit of $\mathrm{AO}$ and enzyme solution in a final volume of $700 \mu \mathrm{L}$. The reaction was started by the addition of AO. The activity was calculated from the change in ascorbate at $340 \mathrm{~nm}$ for $1 \mathrm{~min}$ using an extinction coefficient of $6.2 \mathrm{mM}-1 \mathrm{~cm}-1$.

Dehydroascorbate reductase (EC: 1.8.5.1) activity was determined by the procedure of Nakano and Asada (1981). The reaction buffer contained $50 \mathrm{mM} \mathrm{K}$-phosphate buffer (pH 7.0), $2.5 \mathrm{mM}$ GSH, and $0.1 \mathrm{mM}$ DHA. The reaction was started by adding the sample solution to the reaction buffer solution. The activity was calculated from the change in absorbance at $265 \mathrm{~nm}$ for $1 \mathrm{~min}$ using an extinction coefficient of $14 \mathrm{mM}-1 \mathrm{~cm}-1$.

Glutathione reductase (EC: 1.6.4.2) activity was measured by the method of Hossain et al. (2006). The reaction mixture contained $0.1 \mathrm{M} \mathrm{K}$-phosphate buffer $(\mathrm{pH}$ 7.8), $1 \mathrm{mM}$ EDTA, $1 \mathrm{mM}$ GSSG, $0.2 \mathrm{mM}$ NADPH, and enzyme solution in a final volume of $1 \mathrm{ml}$. The reaction was initiated with GSSG and the decrease in absorbance at 340 $\mathrm{nm}$ due to NADPH oxidation was recorded for $1 \mathrm{~min}$. The activity was calculated using an extinction coefficient of 6.2 $\mathrm{mM}-1 \mathrm{~cm}-1$.

Glutathione S-transferase (EC: 2.5.1.18) activity was determined spectrophotometrically by the method of Hossain et al. (2006) with some modifications. The reaction mixture contained $100 \mathrm{mM}$ Tris- $\mathrm{HCl}$ buffer $(\mathrm{pH}$ 6.5), $1.5 \mathrm{mM}$ GSH, $1 \mathrm{mM}$ 1-chloro-2, 4-dinitrobenzene (CDNB) and enzyme solution in a final volume of $700 \mu \mathrm{L}$. The enzyme reaction was initiated by the addition of $\mathrm{CDNB}$ and the increase in absorbance was measured at 340 $\mathrm{nm}$ for $1 \mathrm{~min}$. The activity was calculated using the extinction coefficient of $9.6 \mathrm{mM}-1 \mathrm{~cm}-1$.

POD activity was determined by the method of Shannon et al. (1966). The reaction mixture contained 2.9 $\mathrm{ml}$ of $0.1 \mathrm{M}$ phosphate buffer ( $\mathrm{pH} 7.0), 0.04 \mathrm{ml}$ of $0.1 \mathrm{M}$ $\mathrm{H} 2 \mathrm{O} 2,0.04 \mathrm{ml}$ of $0.2 \% \mathrm{O}$-dianisidine and $0.02 \mathrm{ml}$ of enzyme extract. The change in absorbance was read at 470 $\mathrm{nm}$ for $4 \mathrm{~min}$. One enzyme unit is defined as change in 1 unit of absorbance min-1.

Catalase (EC: 1.11.1.6) activity was measured according 
to the method of Hossain et al. (2006) by monitoring the decrease of absorbance at $240 \mathrm{~nm}$ for $1 \mathrm{~min}$ caused by the decomposition of $\mathrm{H} 2 \mathrm{O} 2$. The reaction mixture contained $50 \mathrm{mM}$ K-phosphate buffer ( $\mathrm{pH} 7.0), 15 \mathrm{mM} \mathrm{H} 2 \mathrm{O} 2$ and enzyme solution in a final volume of $700 \mu \mathrm{L}$. The reaction was initiated with enzyme extract and the activity was calculated using the extinction coefficient of $39.4 \mathrm{M}-1 \mathrm{~cm}-1$.

\section{Measurement of yield and yield contributing parameter}

Plant height was measured from the soil level to the apex of the leaf or spike in randomly 5 plants of each pot. The total number of tillers hill-1 was counted from selected samples and grouped in effective and non-effective tillers plant-1. Then spike length was recorded from the basal nodes of the rachis to apex of each spike. Grains of 5 randomly selected spike of each replication were counted and then the average number of grains for each spike was determined. One hundred clean sun dried grains were counted from the seed stock obtained from the sample plants and weighed by using an electronic balance. Then it was converted into thousand grain weight. The grains were separated by threshing per plant and then sun dried and weighed. The straw was separated by threshing per plant and weighed. Biological yield was calculated by using the following formula:

Biological yield $=$ Grain yield + straw yield

Finally harvest index was calculated by using the following formula of Gardner et al. (1985):

Harvest index $(\mathrm{HI})=($ Grain Yield $) /($ Biological Yield) $\times 100$

\section{Statistical analysis}

The data obtained for different parameters were statistically analyzed following computer based software XLSTAT 2014 (AddinSoft, 2014) and mean separation was done by LSD at $5 \%$ level of significance.

\section{Results}

\section{Relative water content ( $R W C$ )}

Upon exposure to salt stress, leaf relative water content decreased significantly in both wheat varieties when compared to their controls (Fig. 1A). However, decline in RWC was lower in 'BARI Gom 25' as compared to 'BARI Gom 21'. Addition of SA, in combination with salt stress significantly increased relative water content in both varieties, compared to addition of salt only. But, in case of $200 \mathrm{mM} \mathrm{NaCl}$, SA treatment could not increase relative water content of wheat plant.

\section{Chlorophyll content}

Chlorophyll content is also affected by salinity stress, according to Fig. 1B. In case of 'BARI Gom 21', chlorophyll content decreased $19,23,28$, and $31 \%$ at 50,100, 150 and $200 \mathrm{mM} \mathrm{NaCl}$, respectively (Fig. 1B). On the contrary, reductions in chl content were $12,23,26$ and $28 \%$ at 50 , 100,150 and $200 \mathrm{mM} \mathrm{NaCl}$, respectively. Though SA treatment significantly increased the chl content under stress condition but it failed to increase chl content under $200 \mathrm{mM} \mathrm{NaCl}$. However, when plant treated with SA only, chl content was not affected significantly in relation to control.

\section{Lipidperoxidation and $\mathrm{H}_{2} \mathrm{O}_{2}$ level}

The malondealdehyde (MDA) content (indicator of lipid peroxidation) sharply increased at any level of salt stress in both wheat varieties (Fig. 2A). The highest amount of MDA content was noted in the case of $200 \mathrm{mM} \mathrm{NaCl}$, whereas the lowest amount of MDA content was found when seedling were treated with SA alone in salt sensitive and salt tolerant variety respectively. However, the rate on increment was higher in salt sensitive 'BARI Gom 21' (Fig. 2A). The levels of $\mathrm{H} 2 \mathrm{O} 2$ also increased noticeably upon exposure to $\mathrm{NaCl}$. In 'BARI Gom 21', the $\mathrm{H} 2 \mathrm{O} 2$ content was increased by 93 and $184 \%$ at 150 and $200 \mathrm{mM} \mathrm{NaCl}$,

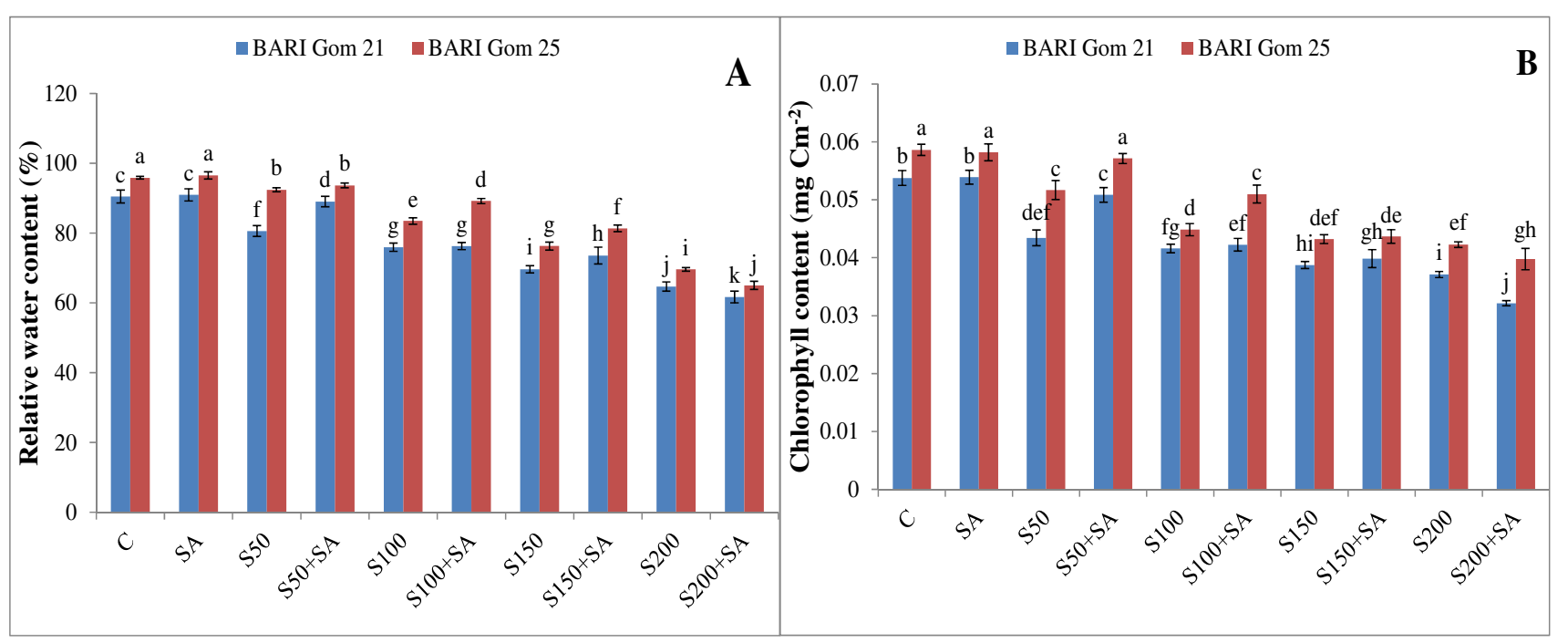

Fig. 1. (A) Leaf relative water content and (B) chlorophyll content in salt sensitive and salt tolerant wheat plants induced by exogenous salicylic acid under salt stress. S50, S100, S150 and S200 indicate $50 \mathrm{mM}, 100 \mathrm{mM}, 150 \mathrm{mM}$ and $200 \mathrm{mM} \mathrm{NaCl}$, respectively. SA indicates $1 \mathrm{mM}$ salicylic acid spray, respectively. Mean $( \pm S D)$ was calculated from three replicates for each treatment. Values in a column with different letters are significantly different at $p \leq 0.05$ applying LSD test 


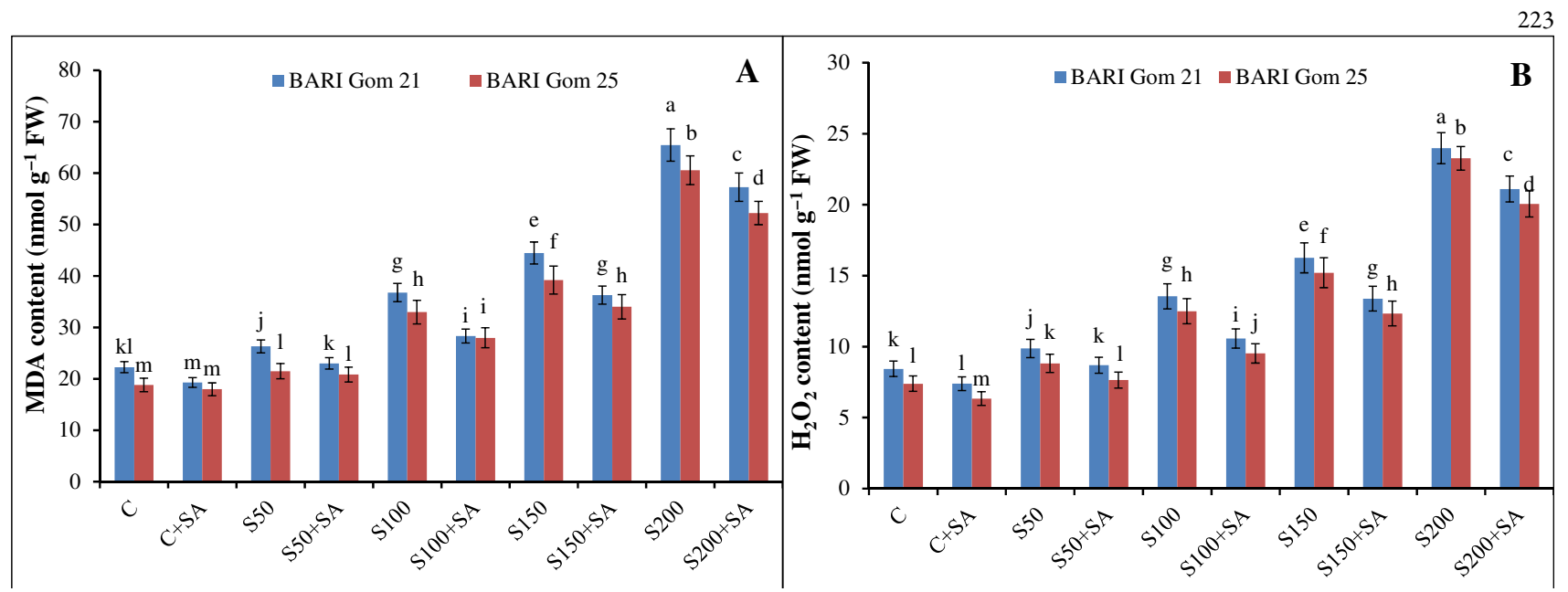

Fig. 2. (A) MDA content and (B) $\mathrm{H}_{2} \mathrm{O}_{2}$ content in salt sensitive and salt tolerant wheat plants induced by exogenous salicylic acid under salt stress. S50, S100, S150 and S200 indicate $50 \mathrm{mM}, 100 \mathrm{mM}, 150 \mathrm{mM}$ and $200 \mathrm{mM} \mathrm{NaCl}$, respectively. SA indicates 1 $\mathrm{mM}$ salicylic acid spray, respectively. Mean $( \pm S D)$ was calculated from three replicates for each treatment. Values in a column with different letters are significantly different at $p \leq 0.05$ applying LSD test

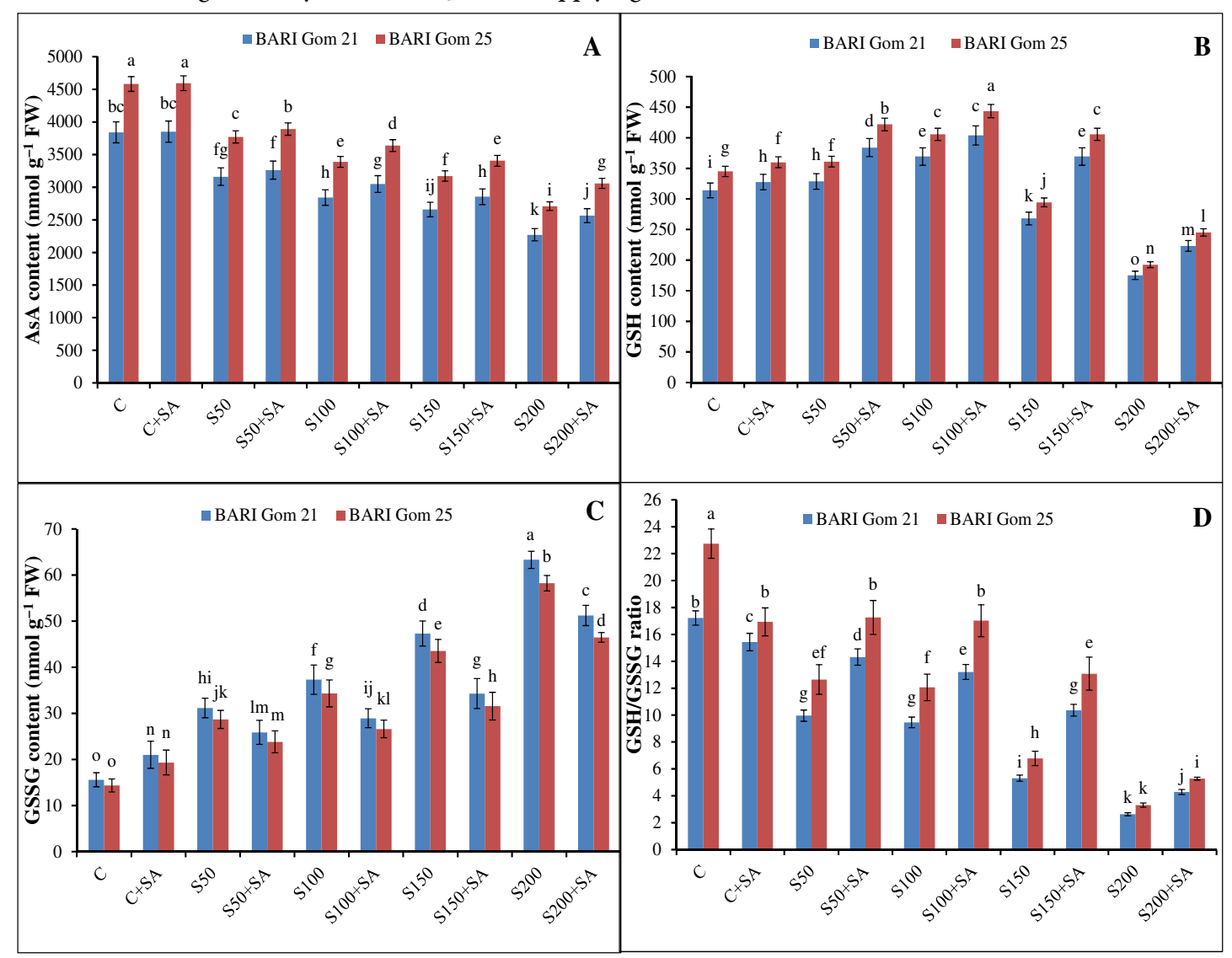

Fig. 3. (A) AsA content, (B) GSH content, (C) GSSG content and (D) GSH/GSSG ratio in salt sensitive and salt tolerant wheat plants induced by exogenous salicylic acid under salt stress. S50, S100, S150 and S200 indicate $50 \mathrm{mM}, 100 \mathrm{mM}, 150 \mathrm{mM}$ and $200 \mathrm{mM} \mathrm{NaCl}$, respectively. SA indicates $1 \mathrm{mM}$ salicylic acid spray, respectively. Mean $( \pm \mathrm{SD})$ was calculated from three replicates for each treatment. Values in a column with different letters are significantly different at $p \leq 0.05$ applying LSD test

while in 'BARI Gom 25' it was increased by 106 and 215\%, respectively, compared to control (Fig. 2B). SA could maintain the $\mathrm{H}_{2} \mathrm{O}_{2}$ content lower in salt-stressed seedlings compared to the seedlings grown without SA supplementation (Fig. 2B). In all cases there was significant difference between 'BARI Gom 21' and 'BARI Gom 25' in respect of $\mathrm{H}_{2} \mathrm{O}_{2}$ content.

\section{Antioxidant defense system}

According to (Fig. 3A) gradual decrease in AsA content over control was observed, for both 'BARI Gom 21' and 'BARI Gom 25', as the plant exposed to salt stress. Compared to control AsA content decrease 18, 26, 31 and $41 \%$ in case of 'BARI Gom 21' and 'BARI Gom 25' due to $50,100,150$ and $200 \mathrm{mM} \mathrm{NaCl}$. When seedling treated 
224

with SA, AsA content increases significantly for all cases. AsA content of 'BARI Gom 25' was always higher than that of 'BARI Gom 21'. There was no significant difference between control and SA treated alone seedling AsA content for both varieties. Significant increase in GSH content were observed ( 5 and $18 \%$ by the 50 and $100 \mathrm{mM} \mathrm{NaCl}$ stresses respectively) in response to salt stress, compared to the untreated control (Fig. 3B). However, sharp decrease was also observed when plant exposed to 150 and $200 \mathrm{mM}$ $\mathrm{NaCl}$ for both genotypes. An increase in GSH content was also observed in $S A$ treated salt-stressed seedlings and, particularly at the $100 \mathrm{mM} \mathrm{NaCl}$, the SA treated seedlings showed a significant increase (9\%) in GSH content compared to seedlings of 'BARI Gom 21' and 'BARI Gom 25 ' subjected to salt stress alone. The highest amount of GSSG content was 63 and $58 \mathrm{nmol}$ g-1 FW salinity level $200 \mathrm{mM} \mathrm{NaCl}$, whereas the lowest amount of MDA content were 16 and $14 \mathrm{nmol}$ g-1 FW found when seedling without stress treatment or SA in salt sensitive 'BARI Gom 21 ' and salt tolerant 'BARI Gom 25' variety respectively (Fig. 3C). In salt sensitive 'BARI Gom 21' the levels were increased by 139 and $305 \%$ at 100 and $200 \mathrm{mM} \mathrm{NaCl}$, respectively. Exogenous SA, on the other hand, maintained the GSSG content significantly lower under salt stress compared to the seedlings grown without SA supplementation. The ratio of GSH/GSSG decreased markedly under salt stress in dose dependent manners and it greatly varied with varieties (Fig. 3D). In salt sensitive 'BARI Gom 21', 150 and $200 \mathrm{mM} \mathrm{NaCl}$ resulted in 69 and $85 \%$ decrease in GSH/GSSG ration, while in salt tolerant 'BARI Gom 25', it decreased by 70 and $85 \%$, respectively, compared to control (Fig. 3D). In all cases there was significant difference between 'BARI Gom 21' and 'BARI
Gom 25' in respect of GSH/GSSG except at $200 \mathrm{mM}$ $\mathrm{NaCl}$.

Imposition of salt stress of $100 \mathrm{mM} \mathrm{NaCl}$ significantly increased the APX activity by $30 \%$ in salt sensitive 'BARI Gom 21', while in salt tolerant 'BARI Gom 25' it was increased by $31 \%$ compared to control. APX activity was decreased by $12 \%$ in salt sensitive cultivar and $11 \%$ in salt tolerant cultivar (Fig. 4A). Exogenous SA supplementation in salt stressed seedlings maintained higher APX activities, compared to salt stress alone, whereas in salt tolerant 'BARI Gom 25' the activity was always higher than 'BARI Gom 21' (Fig. 4A). In salt sensitive 'BARI Gom 21', the activity decreased by any level of salt stress ( 24 and 39\% lower at 100 and $200 \mathrm{mM} \mathrm{NaCl}$, respectively, compared to the control). Salt tolerant 'BARI Gom 25' showed significant increase in CAT activity under mild stress $(50 \mathrm{mM} \mathrm{NaCl})$, whereas a noticeable decrease (23\%) was observed at severe stress (200 $\mathrm{mM}$ ). However, exogenous SA enhanced the CAT activity in salt-treated seedlings (Fig. 5A). Salt stress at any level decreased the MDHAR activity. The highest activity was 43 nmol min-1 mg-1 protein found 'BARI Gom 25' treated with SA alone, while the lowest MDHAR activity was 26 $\mu \mathrm{mol}$ min-1 mg-1 protein found in 'BARI Gom 21' exposed to $200 \mathrm{mM} \mathrm{NaCl}$. Exogenous SA addition under any levels of salt stress significantly increased MDHAR activities irrespective of cultivars (Fig. 4B). Salt stress caused a marked decrease in DHAR activity at any level of stress except when seedling exposed to $200 \mathrm{mM} \mathrm{NaCl}$. In 'BARI Gom 21', due to exogenous SA application DHAR activities were increased by 10 and $21 \%$ at 150 and $200 \mathrm{mM} \mathrm{NaCl}$, respectively. In 'BARI Gom 25', exogenous SA supplemented seedlings showed increased DHAR activities by $25 \%$ at $150 \mathrm{mM} \mathrm{NaCl}$, however no significant change in

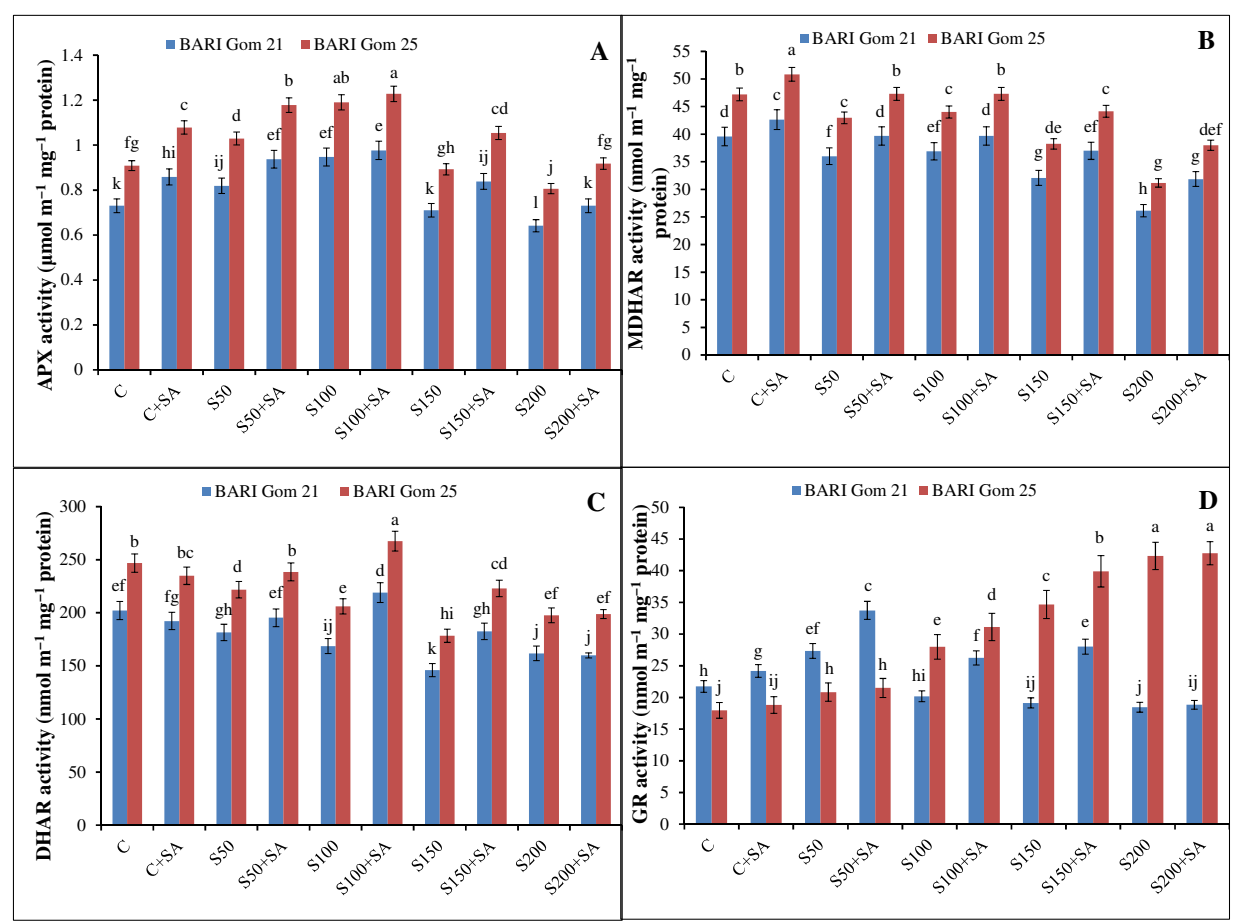

Fig. 4. (A) APX activity, (B) MDHAR activity, (C) DHAR activity and (D) GR activity in salt sensitive and salt tolerant wheat plants induced by exogenous salicylic acid under salt stress. S50, S100, S150 and S200 indicate $50 \mathrm{mM}, 100 \mathrm{mM}, 150 \mathrm{mM} \mathrm{NaCl}$ and $200 \mathrm{mM} \mathrm{NaCl}$, respectively. In Y-axis, $\mathrm{m}^{-1}$ indicates 'per minute'. SA indicates $1 \mathrm{mM}$ salicylic acid spray, respectively. Mean $( \pm S D)$ was calculated from three replicates for each treatment. Values in a column with different letters are significantly different at $p \leq 0.05$ applying LSD test. 


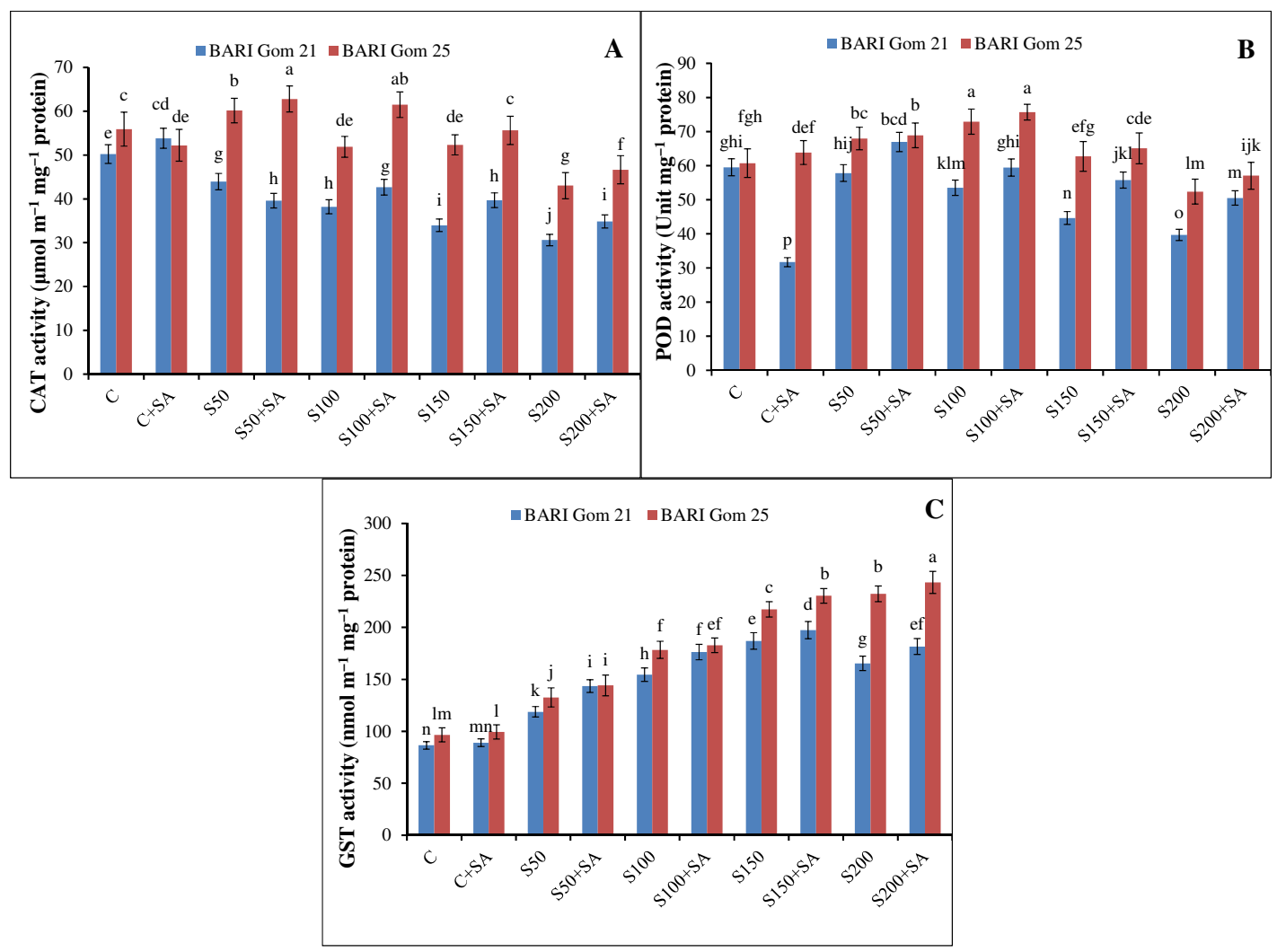

Fig. 5. (A) CAT activity, (B) POD activity and (C) GST activity in salt sensitive and salt tolerant wheat plants induced by exogenous salicylic acid under salt stress. S50, S100, S150 and S200 indicate $50 \mathrm{mM}, 100 \mathrm{mM}, 150 \mathrm{mM} \mathrm{NaCl}$ and $200 \mathrm{mM}$ $\mathrm{NaCl}$, respectively. In Y-axis, $\mathrm{m}^{-1}$ indicates 'per minute'. SA indicates $1 \mathrm{mM}$ salicylic acid spray, respectively. Mean $( \pm S D)$ was calculated from three replicates for each treatment. Values in a column with different letters are significantly different at $p \leq 0.05$ applying LSD test

DHAR activity observed due to SA supplementation at 200 $\mathrm{mM} \mathrm{NaCl}$, compared to salt stress alone (Fig. 4C). Compared to control, the salt sensitive 'BARI Gom 21' had decreased GR activities of $12 \%$ and $15 \%$ in exposure to 150 and $200 \mathrm{mM} \mathrm{NaCl}$, respectively (Fig. 4D). In opposition, salt tolerant 'BARI Gom 25 ' had significantly higher GR activities of $35 \%$ and $42 \%$ with 150 and $200 \mathrm{mM} \mathrm{NaCl}$, respectively. Nonetheless, exogenous SA enhanced its activity further in both sensitive and tolerant varieties irrespective of salt doses, compared to the activity in the seedlings exposed to salt stress alone (Fig. 4D). Salt stress caused significant decerase in POD activities 25\% and 33\% in 'BARI Gom 21' whereas 'BARI Gom 25' showed 3\% increase and $14 \%$ decrease in POD activity at 150 and 200 $\mathrm{mM} \mathrm{NaCl}$ respectively (Fig. 5B). For 'BARI Gom 25' POD activities ranges from 63 to 76 unit mg-1 protein and in many case showed insignificant difference among different treatment. The activity of GST sharply increased in all wheat seedlings induced by all levels of salt stress although its activity was slightly higher in salt tolerant 'BARI Gom 25' (Fig. 5C). SA increased GST activity significantly. GST activity was higher in all cases except when seedling treated with $\mathrm{SA}$ under $50 \mathrm{mM} \mathrm{NaCl}$.

\section{Yield contributing characters}

Exposure to salt stress resulted in significant decreases in effective tiller number hill-1: 22, 29, 44 and 56\% for 'BARI Gom 21' and 20, 27, 34 and 53\% for 'BARI Gom 25' at 50, 100,150 and $200 \mathrm{mM} \mathrm{NaCl}$, respectively when compared to unstressed control plant (Fig. 6A). Addition of exogenous SA combination with salinity stress significantly increased the effective tiller number up to $150 \mathrm{mM} \mathrm{NaCl}$. Furthermore, in case of $200 \mathrm{mM} \mathrm{NaCl}$ there had no statistically difference from each other of both varieties. Salinity stress caused increased number of non-effective tiller hill-1 of both varieties. The highest non-effective tiller was found in $200 \mathrm{mM}$ salt stressed condition of 'BARI Gom 21' which was treated with SA (Fig. 6B). SA supplementation reduced the number of non-effective tiller in the salt stressed condition. Saline treatment reduced the length of spike compared to control and SA treated plant. At $150 \mathrm{mM} \mathrm{NaCl}$, length of spike was decreased 39\% in 'BARI Gom 21' and $40 \%$ in 'BARI Gom 25' (Fig. 7A). In contrary, exogenous SA supplementation caused increased the length of spike of both varieties. Significantly higher number of spikelet per spike was recorded in controlled condition, only SA treated and SA treated $50 \mathrm{mM} \mathrm{NaCl}$ of 'BARI Gom 25'. After all, both of variety gave same result in case of $200 \mathrm{mM} \mathrm{NaCl}$. SA treated $200 \mathrm{mM} \mathrm{s} \mathrm{NaCl}$ gave significantly lower number of spikelet per spike than 200 $\mathrm{mM} \mathrm{NaCl}$ without treatment for both of variety (Fig. 7B). Marked decreases in 1,000 grain weight were observed in response to salt stress. Anyhow, salt stressed plants treated with SA up to $150 \mathrm{mM} \mathrm{NaCl}$ had significantly higher 1,000 grain weight in both varieties compared to plants which were subjected to salt stress without SA (Fig. 7C). Comparing cultivars, under control conditions, 'BARI Gom $25^{\prime}$ produced more 1,000 grain weight in comparison 


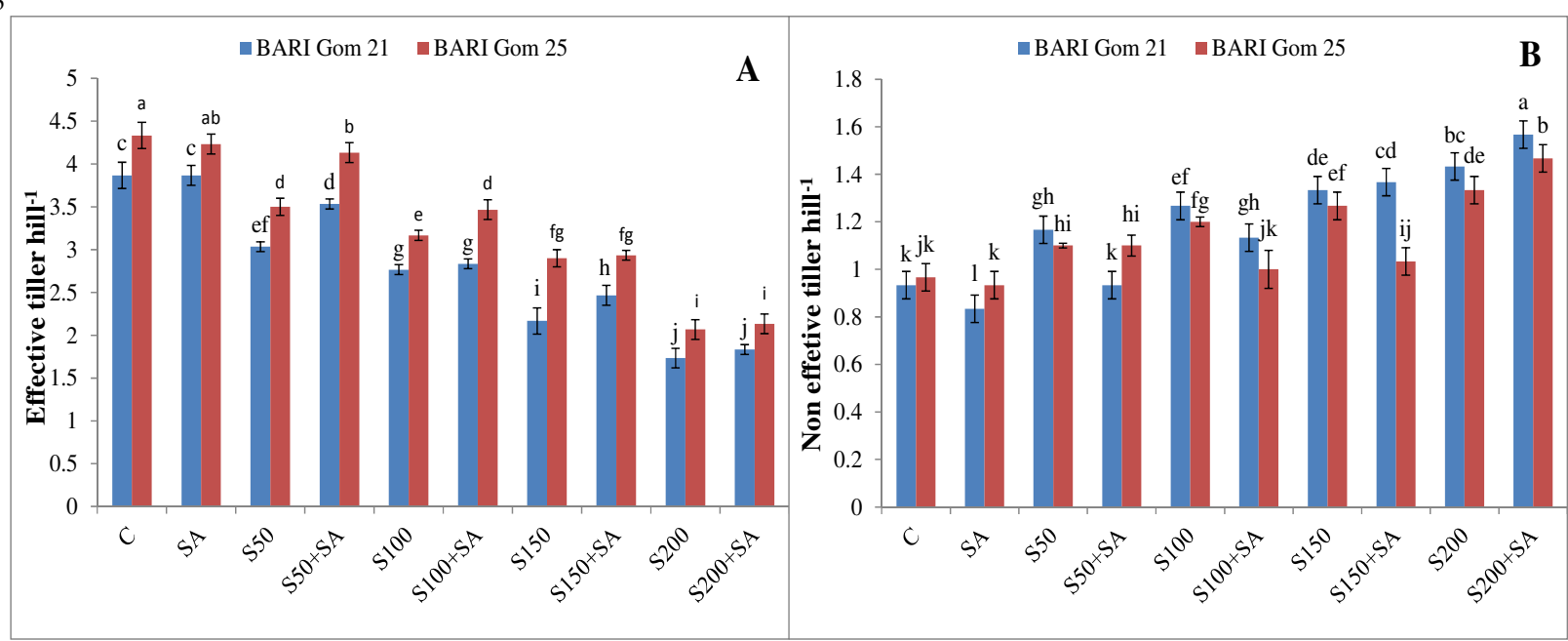

Fig. 6. (A) Effective tiller hill ${ }^{-1}$ and (B) Non effective tiller hill ${ }^{-1}$ in salt sensitive and salt tolerant wheat plants induced by exogenous salicylic acid under salt stress. S50, S100, S150 and S200 indicate $50 \mathrm{mM}, 100 \mathrm{mM}, 150 \mathrm{mM}$ and $200 \mathrm{mM} \mathrm{NaCl}$, respectively. SA indicates $1 \mathrm{mM}$ salicylic acid spray, respectively. Mean $( \pm S D)$ was calculated from three replicates for each treatment. Values in a column with different letters are significantly different at $p \leq 0.05$ applying LSD test

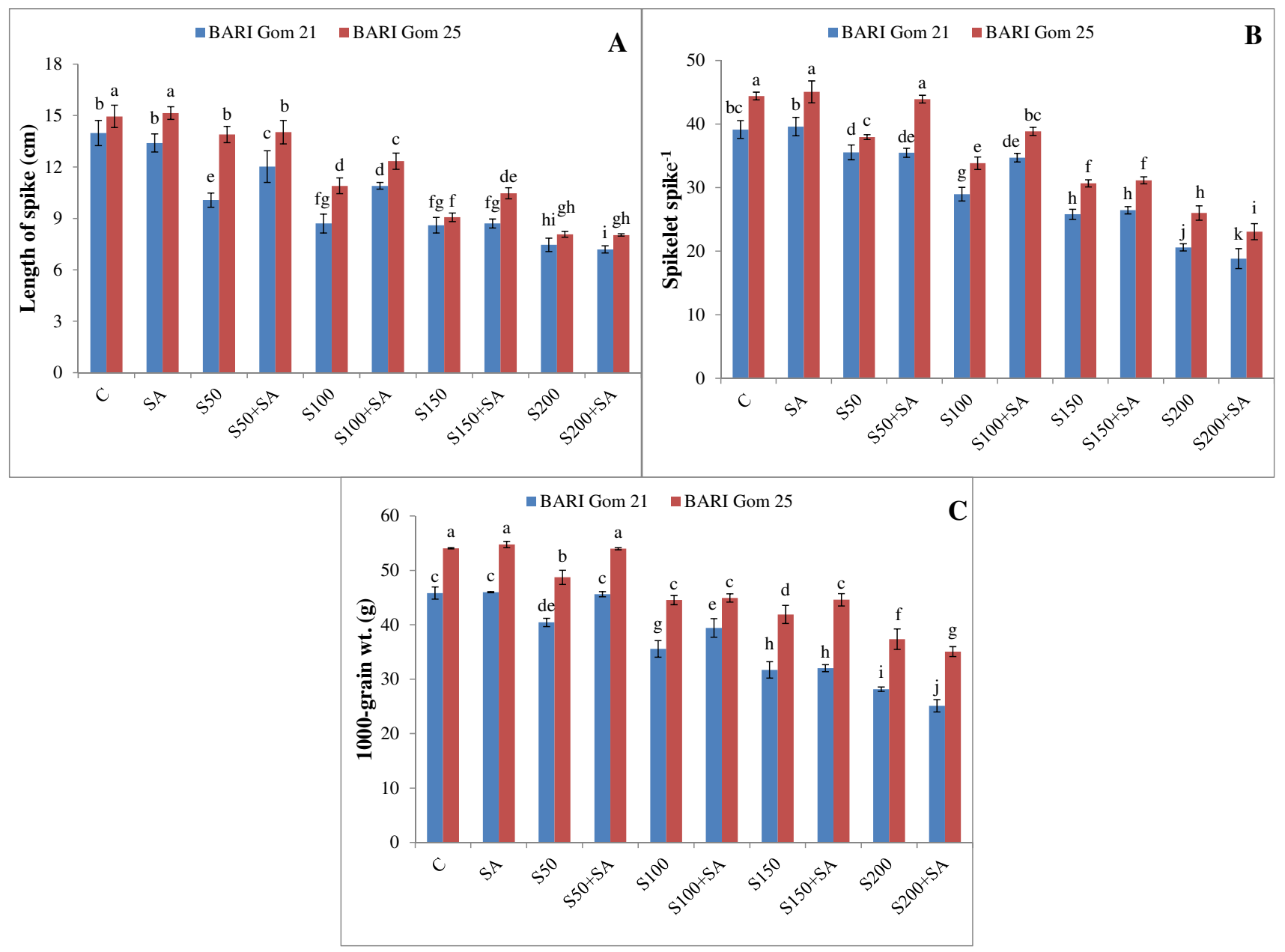

Fig. 7. (A) Length of spike, (B) spikelet spike $\mathrm{e}^{-1}$ and (C) 1,000-grain wt. in salt sensitive and salt tolerant wheat plants induced by exogenous salicylic acid under salt stress. S50, S100, S150 and S200 indicate $50 \mathrm{mM}, 100 \mathrm{mM}, 150 \mathrm{mM}$ and $200 \mathrm{mM} \mathrm{NaCl}$, respectively. SA indicates $1 \mathrm{mM}$ salicylic acid spray, respectively. Mean $( \pm S D)$ was calculated from three replicates for each treatment. Values in a column with different letters are significantly different at $p \leq 0.05$ applying LSD test 


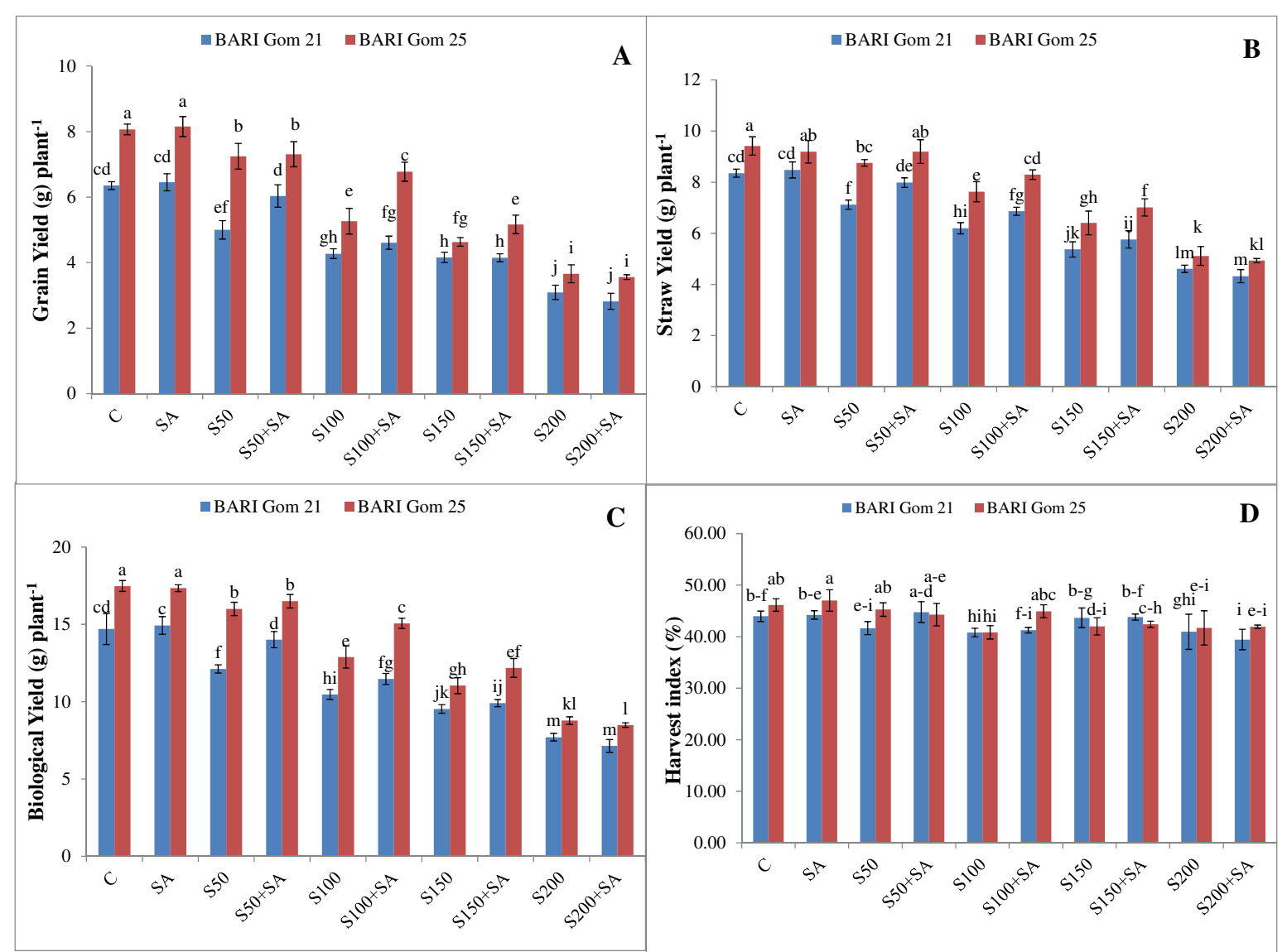

Fig. 8. (A) Grain yield, (B) straw yield, (C) biological yield and (D) harvest index in salt sensitive and salt tolerant wheat plants induced by exogenous salicylic acid under salt stress. S50, S100, S150 and S200 indicate $50 \mathrm{mM}, 100 \mathrm{mM}, 150 \mathrm{mM}$ and $200 \mathrm{mM}$ $\mathrm{NaCl}$, respectively. SA indicates $1 \mathrm{mM}$ salicylic acid spray, respectively. Mean $( \pm S D)$ was calculated from three replicates for each treatment. Values in a column with different letters are significantly different at $p \leq 0.05$ applying LSD test

to 'BARI Gom 21'. However, both wheat cultivars behaved similarly under saline environment.

\section{Yields}

Significant variation was observed for grain yield due to different salinity treatments (Fig. 8A). The highest grain yield was found in control $(40.33 \mathrm{~g})$ and only SA treated plant $(40.77 \mathrm{~g}$ ) of 'BARI Gom 25' variety (Fig. 8A). For all that, the lowest grain yield was found in $200 \mathrm{mM} \mathrm{NaCl}$ of both varieties which was not increased or decreased after treating with SA. Straw yield was noticeably decreased in both wheat varieties under salt stressed condition. Straw yield was decreased by $11,32,42$ and $51 \%$ for 'BARI Gom 21 ' and $15,28,41$ and $50 \%$ for 'BARI Gom 25' at 50, 100, 150 and $200 \mathrm{mM} \mathrm{NaCl}$ respectively, compared to respective control (Fig. 8B). However, exogenous application with SA mitigated the salt effect up to $150 \mathrm{mM} \mathrm{NaCl}$ for both of varieties. The highest amount of biological yield (17.48 and $17.34 \mathrm{~g}$ ) was observed in untreated control and only SA treated plant of 'BARI Gom 25' and the lowest amount of biological yield (7.70 and 7.15 g) was observed in seedling exposed to $200 \mathrm{mM} \mathrm{NaCl}$ and SA treated $200 \mathrm{mM} \mathrm{NaCl}$ condition of 'BARI Gom 21' (Fig. 8C). Sharp decreases in harvest index were observed) in response to salt stress, compared to the respective control and untreated control (Fig. 8D). SA treated salt stressed plants had significantly higher HI, compared to plants subjected to salt stress without SA treatment. However, the level was significantly lower than that of untreated control. The HI of SA treated control plants was similar to that of the untreated control.

\section{Discussion}

Several biochemical and physiological alterations like decrease in water content in plant tissues, decline in photosynthetic pigments and oxidative stress caused by salt stress. A secondary oxidative stress caused by the accumulation of reactive oxygen species (ROS) including singlet oxygen $\left(\mathrm{O}_{2}\right)$, superoxide $\left(\mathrm{O}_{2 .-}\right)$, hydrogen peroxide $\left(\mathrm{H}_{2} \mathrm{O}_{2}\right)$ and hydroxyl radicles $(\mathrm{OH}$.) which generates by salt stress (Ahmad et al., 2011; Hasanuzzaman et al., 2013).

The common phenomenon of plant growth under salt stress is declining RWC and it is considered as the efficient indicator for evaluating plants for tolerance to stress as salt stress causes osmotic stress. In this study, RWC significantly decreased in wheat leaves irrespective to $\mathrm{NaCl}$ concentration and the wheat cultivars due to salt stress (Fig. 1A). There was same result found which was reported earlier in decreasing RWC due to salt stress (Katerji et al., 1997; Vysotskaya et al., 2010; Chaparzadeh and Mehrnejad, 2013). However, supplementation of SA with salt stress increased RWC which was due to the increment of water holding capacity in their leaf tissue (Fig. 1A). Foliar spraying with SA increased RWC under salt stressed condition were 
228

also reported for wheat (El-bassiouny and Bekheta, 2005; Mohammadi et al., 2013) and other crops including Torreya grandis (Li et al., 2014), Brassica napus (Mohammadreza et al., 2012), strawberry (Karlidag et al., 2009), cucumber (Yildirim et al., 2008), barley (El-Tayeb, 2005), tomato (Tari et al., 2002; Szepsi et al., 2005). The RWC was slightly higher in 'BARI Gom 25' compared to 'BARI Gom 21' which was due to its better salt tolerance ability.

In our experiment, Chl content was reduced due to salt stress for both varieties. However, salt sensitive 'BARI Gom 21 ' gave slightly higher reduction compared to salt tolerant 'BARI Gom 25' (Fig. 1B). Photosynthesis pigment biosynthesis alters due to salt stress (Maxwel and Jhonson, 2000). Similarly, the adverse effect of salt stress on chl content was observed in many leaves of plant; Kaya $e t$ al. (2002) in strawberry. However, SA supplementation was mostly turned over this effect (Fig. 1B). These results are in agreement with $\mathrm{Li}$ et al. (2014) for Torreya grandis, Mohammadi et al. (2013) for wheat, Karlidag et al. (2009) for strawberry, Yildirim et al. (2008) for cucumber, Moharekar et al. (2003) for wheat.

The important index of determining the degree of oxidative stress is considered as lipid peroxidation because abiotic stress including salt stress increased MDA content with the extent of oxidative stress (Hasanuzzaman et al., 2011). As oxidation product, MDA formed when ROS such as $\mathrm{OH}$. And $1 \mathrm{O} 2$ attack PUFA (Gill and Tuteja, 2010). Higher accumulation of $\mathrm{H} 2 \mathrm{O} 2$ also causes oxidative stress in plant. In this study, with the increase in salinity level, MDA and $\mathrm{H} 2 \mathrm{O} 2$ content also increased. Foliar spraying with SA reduced MDA and $\mathrm{H} 2 \mathrm{O} 2$ content significantly under salt stress condition (Fig. 2A, B). Exogenous SA treated plant have decreased amount of MDA and $\mathrm{H} 2 \mathrm{O} 2$ were observed by the other researchers (Hasanuzzaman et al., 2014 in Brassica napus, Erdal et al., 2011 in wheat, El-bassiouny and Bekheta, 2005 in wheat).

AsA is able to donate electron to many enzymatic and non-enzymatic reactions what makes it an important ROS scavenging molecule. It can protect membrane by scavenging $\mathrm{OH}$ and $\mathrm{O}_{2}$ - directly regenerating $\alpha$-tocopherol from tocopheroxyl radical (Gill and Tuteja, 2010). GSH is another important substance especially for photosynthetic organelles such as chloroplast. AsA and GSH play vital role in the AsA - GSH cycle to enhance stress tolerance under stress condition (Pastori et al., 2003). AsA - GSH cycle composed of APX, MDHAR, DHAR and GR and these enzymes works coordinately to remove $\mathrm{ROS}$ such as $\mathrm{H} 2 \mathrm{O} 2$ (Kadioglu et al., 2011). AsA content strongly related to oxidative stress tolerance and higher AsA content in plants showed better tolerance to oxidative stress (Nahar et al., 2012). Increased AsA or GSH content can effectively reduce ROS produced under stress conditions including salt stress and thus prevents oxidative stress. In the present study, it is examined that the performance of salt tolerance and salt sensitive wheat cultivars against different salinity levels and we also examined how they are protected from salt stress by exogenous SA application. It was observed that under mild salt stress condition AsA level of salt sensitive 'BARI Gom 21' was reduced whereas the AsA level of 'BARI Gom 21' was higher (Fig. 3A). Severe salt stress also reduced the AsA level of salt sensitive and salt tolerant cultivar. In this study, a slight increase in APX activity was observed in leaves of salt treated seedlings which were supported by Gusman et al. (2013), Tari et al. (2015). However, SA supplementation could not enhance the activity further under severe salt stress (Fig. 4A). This result is correlated to MDHAR and DHAR activities which regulate the recycling of AsA within the cell. From Fig. 4B and $4 \mathrm{C}$ it is clear that when the MDHAR or DHAR activity was reduced in salt sensitive 'BARI Gom 21', then its AsA levels were reduced irrespective of different salt doses. The higher MDHAR and DHAR activities of salt tolerant 'BARI Gom 21' were also related to its AsA levels. In our experiment, the GSH content (Fig. 3B) also increased with increased salinity stress, but decrease under severe stress. Similar results reported by Hasanuzzaman et al. (2014) and Alam et al. (2013). The increased GSH content might be due to the increase in GR activities as well as higher GSH biosynthesis (Mittova et al., 2004). Under stressful condition GR helps in maintaining the GSH redox state by recycling of GSSG to GSH. It also plays a vital role in maintenance of sulfhydryl $(-\mathrm{SH})$ group and acts as a substrate for glutathione S-transferases (Yusuf et al., 2012). However, supplementation with SA under salinity stress showed significant increase of both AsA and GSH (Fig. 3A, B) which indicated a clear role of SA in producing nonenzymatic antioxidant. SA might took part in the regeneration of AsA by up-regulating the related enzymes i.e. MDHAR and DHAR; SA also accelerated efficient recycling of GSH is also ensured by GR activity. In this experiment salt stress could increase the GR activity to a small extent. However, when SA treated seedlings were subjected to salt stress the activity markedly increased which rendered rapid recycling of GSH in line with better synthesis of GSH under salt stress conditions (Fig. 4D). The role of SA in enhancing the activity of GR was reported in many plant studies (He and Zhu, 2008). Earlier, it was reported the correlation between enhanced GR activity and better GSH levels as well as abiotic stress tolerance including salinity (Hasanuzzaman et al., 2011; Hasanuzzaman and Fujita, 2011; Hasanuzzaman and Fujita, 2013). In this study, AsA-GSH cycle actively work in tolerant varieties than that of susceptible varieties supported by Sekmen $e t$ al. (2007), Aghaei et al. (2009), Hasanuzzaman et al. (2014).

In our experiment, the GSSG content at severe salinity stress was astonishingly higher (Fig. 3C) than control ones. This increase might be partly attributed to a decrease in the rate of GSH recycling or to an increase in the rate of degradation of GSH (Noctor and Foyer, 1998). However, SA treated salinity-stressed seedlings showed significantly lower GSSG (Fig. 3C). The GSH/GSSG ratio also markedly enhanced by SA application under salt stress condition (Fig. 3D). It has been suggested that the GSH/GSSG ratio, indicative of the cellular redox balance, may be involved in ROS perception (Shao et al., 2005). Similar observations were reported by several researchers (Kadioglu et al., 2011; Hasanuzzaman and Fujita, 2011; Nahar et al., 2012).

Catalase is one of the vital enzymes in scavenging $\mathrm{H} 2 \mathrm{O} 2$ in plant cells exposed to various abiotic stresses due its higher turnover rate of reaction (Garg and Manchanda, 2009). The role of CAT in scavenging $\mathrm{H} 2 \mathrm{O} 2$ was observed 
in several studies (Hasanuzzaman et al., 2011; Hasanuzzaman and Fujita, 2013). In this study, CAT activity was significantly decreased upon exposure to salt stress in susceptible variety 'BARI Gom 21' and this decrease in CAT activity in 'BARI Gom 21' under salt stress might be due to its inactivation by the accumulated $\mathrm{H} 2 \mathrm{O} 2$ induced by water shortage or ineffective enzyme synthesis or change in assembly of enzyme sub-units (Gupta et al., 2009). On the other hand, CAT activity was significantly increased at mild salt stress and decreased under severe salt stress in 'BARI Gom 21' (Fig. 5A) (Gupta et al., 2009; Khan et al., 2009). This trend was supported by earlier reports (Azooz et al., 2009; Lin et al., 2010; Hasanuzzaman et al., 2014). On the contrary, SA-supplemented salt-stressed seedlings showed enhanced activity CAT than those under salt treatment without $S A$ which suggests an unambiguous role of SA in scavenging $\mathrm{H} 2 \mathrm{O} 2$ under salt stress. Similar increases in CAT activity after SA supplementation was observed under salt stress by other researchers (Yusuf et al., 2008; Noriega et al., 2012). POD activity increased under salinity stress (Rohman et al., 2015; Li et al., 2014). In this study, POD activity increased at mild stress but decreased at severe stress. In higher plants, $\mathrm{H} 2 \mathrm{O} 2$ is scavenged by the ascorbate-glutathione pathway and/or by CAT and nonspecific PODs (Scandalios, 2005; Miller et al., 2010). CAT, POD and APX are reported to scavenge $\mathrm{H} 2 \mathrm{O} 2$ to water in plant species (Gill and Tujeta, 2010; Miller et al., 2010). The increased activities of POD and GPX under salt stress played important role in $\mathrm{H} 2 \mathrm{O} 2$ scavenging (Rohman et al., 2015). SA in salt treatments increased the activities of POD (Fig. 5B) which reduced the $\mathrm{H} 2 \mathrm{O} 2$ level and MDA production as well. Li et al. (2014) found upregulation of SOD, POD, CAT and APX by application of SA in salt stressed $T$. grandis seedlings. Plant GSTs are also associated with responses to various forms of abiotic stress (Hossain $e t$ al., 2006; Dixon et al., 2010) and stress tolerance is often correlated with enhanced activity of GST (Hasanuzzaman et al., 2012a, b). In both wheat varieties of our experiment, GST activity markedly increased under salt stress where comparatively higher activity was observed in salt tolerant 'BARI Gom 21' (Fig. 5C). The hereby results are partially supported by Hoque et al. (2008) and Hasanuzzaman et al. (2014).

A result of the assimilation of metabolic reactions in plants is yield; consequently, yield can be affected by this metabolic activity at any period of plant growth which is influenced by any factor (Ibrahim and Aldesuquy, 2003). In this study, salt stress reduced yield and yield attributes such as spike length, effective tiller plant-1, non-effective tiller plant-1, number of spikelet spike-1, 1,000 grain weight, grain yield, straw yield, biological yield and harvest index in both wheat cultivars (Fig. 6(A, B), 7(A-C) and 8(A-D)). The reduction of photosynthetic pigments, carbohydrates accumulation (polysaccharides) and nitrogenous compounds (total nitrogen and protein) attributes the reduction of yield under salt stressed condition. Yield and yield components reduction under similar condition have also been reported by the other researchers for different crops (Aldesuquy et al., 2012 for wheat; Sankar et al., 2008 for Abelmoschus esculentus and Arfan et al., 2007 for wheat). They clearly indicated that salt tolerant genotypes showed less reduction in yield plants in respect of susceptible ones. Therefore, under salt stress condition 'BARI Gom 25' had better yield than that of 'BARI Gom 21'. However, SA treated plants under salt stress condition increased in all the studied yield criteria. These findings are in agreement with those reported by $\mathrm{Ali}$ and Mahmoud (2013), Arfan et al. (2007) and Singh and Usha (2003) on wheat, Gunes et al. (2007) on maize and Elwan and ElHamahmy (2009) on pepper. Arfan et al. (2007) reported that, under saline condition grain yield increasing along with increase in 100 grain weight, number of grains and number of spikelets spike-1 with SA application.

\section{Conclusions}

Based on the results of the present experiment, it can be therefore, concluded that exogenous SA spray is an effective way to overcome the adverse effects of osmotic stress on growth, physiology and yield components of wheat. It could be partially attributed to the increase in non-enzymatic and enzymatic antioxidants. In all the cases, 'BARI Gom 25' was a better performer under salt stress compared to salt sensitive 'BARI Gom 21'. All parameters decreased at any level of salt stress. Exceptions were abnormal seedling, noneffective tiller hill-1, MDA content, H2O2, GSSG content and GST activity which increased in response to salinity.

\section{Acknowledgements}

The authors acknowledge the Ministry of Science and Technology, Government of the People's Republic of Bangladesh for providing National Science and Technology for financial support. They thank Dr. Kamrun Nahar and Taufika Islam Anee of Sher-e-Bangla Agricultural University for their critical reading and formatting of the manuscript.

\section{References}

Addinsoft (2014). XISTAT v. 2014.2.03: Data analysis and statistics software for Microsoft Excel. Addinsoft, Paris, France.

Aghaei K, Ehsanpour AA, Komatsu S (2009). Potato responds to salt stress by increased activity of antioxidant enzymes. Journal of Integrative Plant Biology 51(12):1095-1103.

Ahmad P, Nabi G, Ashraf M (2011). Cadmium-induced oxidative damage in mustard [Brassica juncea (L.) Czern. and Coss.] plants can be alleviated by salicylic acid. South African Journal of Botany 77(1):36-44.

Alam MM, Hasanuzzaman M, Nahar K, Fujita M (2013). Exogenous salicylic acid ameliorates short-term drought stress in mustard (Brassica juncea L.) seedlings by up-regulating the antioxidant defense and glyoxalase system. Australian Journal of Plant Science 7(7):1053-1063.

Aldesuquy HS, Abo-Hamed SA, Abbas MA, Elhakem AH (2012). Role of glycine betaine and salicylic acid in improving growth vigour and physiological aspects of droughted wheat cultivars. Journal of Stress Physiology and Biochemistry 8(1):149-171. 
230

Ali EA, Mahmoud AM (2013). Effect of foliar spray by different salicylic acid and zinc concentrations on seed yield and yield components of Mungbean in sandy soil. Asian Journal of Crop Science 5(1):33-40.

Arfan M, Athar HR, Ashraf M (2007). Does exogenous application of salicylic acid through the rooting medium modulate growth and photosynthetic capacity in two differently adapted spring wheat cultivars under salt stress? Journal of Plant Physiology 164(6):685694.

Azooz MM, Ismail AM, Elhamd MFA (2009). Growth, lipid peroxidation and antioxidant enzyme activities as a selection criterion for the salt tolerance of maize cultivars grown under salinity stress. International Journal of Agriculture and Biology 11(1):21-26.

Barrs HD, Weatherley PE (1962). A re-examination of the relative turgidity technique for estimating water deficits in leaves. Australian Journal of Biological Sciences 15:413-428.

Bradford MM (1976). A rapid and sensitive method for the quantitation of microgram quantities of protein utilizing the principle of protein-dye binding. Analytical Biochemistry 72:248254.

Chaparzadeh N, Mehrnejad F (2013). Oxidative markers in five Iranian alfalfa (Medicago sativa L.) cultivars under salinity stress. Iranian Journal of Plant Physiology 3(4):793-799.

Dixon DP, Skipsey M, Edwards R (2010). Roles for glutathione transferases in plant secondary metabolism. Phytochemistry 71(4):338-350.

El-Bassiuny HMS, Bakheta MA (2005). Effect of salt stress on relative water content, lipid peroxidation, polyamines, amino acids and ethylene of two wheat cultivars. International Journal of Agriculture and Biology 7(3):363-368.

El-Tayeb MA (2005). Response of barley grains to the interactive effect of salinity and salicylic acid. Plant Growth Regulation 45(3):215224.

Elwan MWM, El-Hamahmy MAM (2009). Improved productivity and quality association with salicylic acid application in green house pepper. Scientia Horticulturae 122(4):521-526.

Erdal S, Aydın M, Genisel M, Taspinar MS, Dumlupinar R, Kaya O, Gorcek Z (2011). Effects of salicylic acid on wheat salt sensitivity. African Journal of Biotechnology 10(30):5713-5718.

Gardner FP, Pearce RB, Mitchell RL (1985). Physiology of crop plants. Iowa State University Press, Iowa.

Garg N, Manchanda G (2009). ROS generation in plants: boon or bane? Plant Biosystems 143(1):81-96.

Gill SS, Tuteja N (2010). Polyamines and abiotic stress tolerance in plants. Plant Signaling and Behavior 5(1):6-33.

Gunes A, Inal A, Alpaslan M, Eraslan F, Bagci EG, Cicek N (2007). Salicylic acid induced changes on some physiological parameters symptomatic for oxidative stress and mineral nutrition in maize (Zea mays L.) grown under salinity. Journal of Plant Physiology 164(6):728-736.

Gupta M, Sharma P, Sarin NB, Sinha AK (2009). Differential response of arsenic stress in two varieties of Brassica juncea L. Chemosphere 74(9):1201-1208.

Gusman GS, Oliveira JA, Farnese FS, Cambraia J (2013). Mineral nutrition and enzymatic adaptation induced by arsenate and arsenite exposure in lettuce plants. Plant Physiology and Biochemistry 71:307-314.

Hasanuzzaman M, Alam MM, Nahar K, Mahmud JA, Ahamed KU, Fujita M (2014). Exogenous salicylic acid alleviates salt stressinduced oxidative damage in Brassica napus by enhancing the antioxidant defense and glyoxalase systems. Australian Journal of Plant Science 8(4):631-639.

Hasanuzzaman M, Fujita M (2011). Selenium pretreatment upregulates the antioxidant defense and methylglyoxal detoxification system and confers enhanced tolerance to drought stress in rapeseed seedlings. Biological Trace Element Research 143(3):1758-1776.

Hasanuzzaman M, Fujita M (2013). Exogenous sodium nitroprusside alleviates arsenic-induced oxidative stress in wheat (Triticum aestivum L.) seedlings by enhancing antioxidant defense and glyoxalase system. Ecotoxicology 22(3):584596.

Hasanuzzaman M, Hossain MA, da Silva JAT, Fujita M (2012a). Plant responses and tolerance to abiotic oxidative stress: antioxidant defense is a key factor. In: Bandi V, Shanker AK, Shanker C, Mandapaka M (Eds.) Crop stress and its management: perspectives and strategies. Springer, Berlin pp 261-316.

Hasanuzzaman M, Hossain MA, Fujita M (2011). Selenium-induced up-regulation of the antioxidant defense and methylgyoxal detoxification system reduces salinity-induced damage in rapeseed seedlings. Biological Trace Element Research 143(3):1704-1721.

Hasanuzzaman M, Hossain MA, Fujita M (2012b). Exogenous selenium pretreatment protects rapeseed seedlings from cadmiuminduced oxidative stress by up regulating the antioxidant defense and methylglyoxal detoxification systems. Biological Trace Element Research 149(2):248-261.

Hasanuzzaman M, Nahar K, Fujita M (2013). Extreme temperatures, oxidative stress and antioxidant defense in plants. Abiotic StressPlant Responses and Applications in Agriculture. In: Vahdati K, Leslie C (Eds).Tech, Rijeka, Croatia pp 169-205.

Hasanuzzaman M, Nahar K, Fujita M (2013). Plant response to salt stress and role of exogenous protectants to mitigate saltinduced damages. In: Ahmad P, Azooz MM, Prasad MNV (Eds). Ecophysiology and Responses of Plants under Salt Stress. Springer, New York, USA pp 25-87.

Hayat Q, Hayat S, Irfan M, Ahmad A (2010). Effect of exogenous salicylic acid under changing environment: A review. Environmental and Experimental Botany 68(1):1425.

$\mathrm{He} \mathrm{Y,} \mathrm{Zhu} \mathrm{ZJ} \mathrm{(2008).} \mathrm{Exogenous} \mathrm{salicylic} \mathrm{acid} \mathrm{alleviates} \mathrm{NaCl}$ toxicity and increases antioxidative enzyme activity in Lycopersicon esculentum. Biologia Plantarum 52(4):792-795.

Heath RL, Packer L (1968). Photoperoxidation in isolated chloroplasts:I. Kinetics and stoichiometry of fatty acid peroxidation. Archives of Biochemistry and Biophysics 125:189-198.

Hillel D (2000). Salinity management for sustainable irrigation. The World Bank, Washington DC.

Hoque MA, Banu MN, Nakamura Y, Shimoishi Y, Murata Y (2008). Proline and glycinebetaine enhance antioxidant defense and 
methylglyoxal detoxification systems and reduce $\mathrm{NaCl}$-induced damage in cultured tobacco cells. Journal of Plant Physiology 165(8):813-824.

Hossain MZ, Hossain MD, Fujita M (2006). Induction of pumpkin glutathione $S$-transferases by different stresses and its possible mechanisms. Biologia Plantarum 50(2):210-218.

Huang C, He W, Guo J, Chang X, Su P, Zhang L (2005). Increased sensitivity to salt stress in an ascorbate-deficient Arabidopsis mutant. Journal of Experimental Botany 56:3041-3049.

Ibrahim AH, Aldesuquy HS (2003). Glycine betaine and shiki- mic acid induced modification in growth criteria, water relation and productivity of drought Sorghum bicolor plants. Phyton 43(2):351363.

Kadioglu A, Saruhan N, Sağlam A, Terzi R, Acet T (2011). Exogenous salicylic acid alleviates effects of long term drought stress and delays leaf rolling by inducing antioxidant system drought stress and delays leaf rolling by inducing antioxidant system. Plant Growth Regulation 64(1):27-37.

Karlidag H, Yildirim E, Turan M (2009). Salicylic acid ameliorates the adverse effect of salt stress on strawberry. Scientia Agricola (Piracicaba, Brazil) 66(2):180-187.

Katerji N, van Hoorn JW, Hamdy A, Mastrorilli M, Moukarzel E (1997). Osmotic adjustment of sugar beets in response to soil salinity and its influence on stomatal conductance, growth and yield. Agricultural Water Management 34(1):57-69.

Kaya C, Kirnak H, Higgs D, Saltati K (2002). Supplementary calcium enhances plant growth and fruit yield in strawberry cultivars grown at high $(\mathrm{NaCl})$ salinity. Scientia Horticulturae 93(1):65-74.

Khan I, Ahmad A, Iqbal M (2009). Modulation of antioxidant defence system for arsenic detoxification in Indian mustard. Ecotoxicology and Environmental Safety 72(2):626-634.

Li T, Hu Y, Du X, Tang H, Shen C, Wu J (2014). Salicylic acid alleviates the adverse effects of salt stress in Torreya grandis cv. Merrillii seedlings by activating photosynthesis and enhancing antioxidant systems. PLOS one 9(10): e109492.

Lin CJ, Li CY, Linetal SK (2010) Influence of high temperature during grain filling on the accumulation of storage proteins and grain quality in rice (Oryza sativa L.). Journal of Agricultural and Food Chemistry 58(19):10545-10552.

Mahajan S, Tuteja N (2005). Cold, salinity and drought stresses: An overview. Archives of Biochemistry and Biophysics 444(2):139158.

Maxwell K, Johnson GN (2000). Chlorophyll fluorescence-a practical guide. Journal of Experimental Botany 51(345):659-668.

Miller G, Suzuki N, Ciftci-Yilmaz S, Mittler R (2010). Reactive oxygen species homeostasis and signaling during drought and salinity stresses. Plant, Cell and Environment 33(4):453-467.

Mittler R (2002). Oxidative stress, antioxidants and stress tolerance. Trends in Plant Science 7(9):405-410.

Mittova V, Guy M, Tal M, Volokita M (2004). Salinity upregulates the antioxidative system in root mitochondria and peroxisomes of the wild salt-tolerant tomato species Lycopersicon pennellii. Journal of Experimental Botany 55(399):1105-1113.
Mohammadi M, Sara S, Mohammad D, Javad RM, Majid R (2013). Effect of salicylic acid on alleviation of salt stress on growth and some physiological traits of wheat. International Journal of Biosciences 3(2):20-27.

Mohammadreza S, Amin B, Forogh A, Hossin M, Sorayya S (2012). Response of Brassica napus $\mathrm{L}$. grains to the interactive effect of salinity and salicylic acid. Journal of Stress Physiology and Biochemistry 8(2):159-166.

Moharekar ST, Lokhande SD, Hara T, Tanaka R, Tanaka A, Chavan PD (2003). Effect of salicylic acid on chlorophyll and carotenoid contents of wheat and moong seedlings. Photosynthetica 41(2):315-317.

Munns R, Tester M (2008). Mechanisms of salinity tolerance. Annual Review of Plant Biology 59:651-681.

Nahar K, Hasanuzzaman M, Alam MM, Fujita M (2012). Exogenous glutathione alleviates short-term abiotic stress by modulating antioxidant defense and methylgyoxal detoxification system in $V$. radiata seedlings. Proceedings of the Annual Main Meeting of the Society for Experimental Biology (SEB '12), Salzburg, Austria, July.

Nakano Y, Asada K (1981). Hydrogen peroxide is scavenged by ascorbate-specific peroxidase in spinach chloroplasts. Plant and Cell Physiology 22:867-880.

Noctor G, Foyer CH (1998). Ascorbate and glutathione: keeping active oxygen under control. Annual Reviw of Plant Physiology and Plant Molecular Biology 49:249-279.

Noriega G, Caggiano E, Lecube ML, Cruz DS, Batlle A, Tomaro M (2012). The role of salicylic acid in the prevention of oxidative stress elicited by cadmium in soybean plants. Biometals 25(6):1155-1165.

Paradiso A, Berardino R, de Pinto M, di Toppi LS, Storelli FT, de Gara $\mathrm{L}$ (2008). Increase in ascorbate-glutathione metabolism as local and precocious systemic responses induced by cadmium in durum wheat plants. Plant and Cell Physiology 49:362-374.

Pastori GM, Kiddle G, Antoniw J (2003). Leaf vitamin C contents modulate plant defense transcripts and regulate genes that control development through hormone signaling. The Plant Cell 15(4):939-951.

Pérez-López U, Robredo A, Lacuesta M, Sgherri C, Muňoz-Rueda A, Navari-Izzo F, Mena-Petite A (2010). The oxidative stress caused by salinity in two barley cultivars is mitigated by elevated $\mathrm{CO}_{2}$. Physiologia Plantarum 135(1):29-42.

Pitman MG, Läuchli A (2002). Global impact of salinity and agricultural ecosystems. In: Läuchli A, Lüttge U (Eds) Salinity: environment - plants - molecules. Kluwer Dordrecht pp 3-20.

Rohman MM, Begum S, Akhi AH, Ahsan AFMS, Uddin MS, Amiruzzaman M, Banik BR (2015). Protective role of antioxidants in maize seedlings under saline stress: Exogenous proline provided better tolerance than betaine. Bothalia Journal 45(4):17-35.

Sankar B, Jaleel AC, Manivannan P, Kishorekumar A, Somasundaram R, Panneerselvam R (2008). Relative efficacy of water use in five varieties of Abelmoschus esculentus (L.) Moench. under waterlimited conditions. Colloids and Surfaces B: Biointerfaces 62(1): 125-129.

Scandalios JG (2005). Oxidative stress: molecular perception and 
232

transduction of signal triggering antioxidant gene defenses. Brazilian Journal of Medical and Biological Research 38(7):995-1014.

Sekmen AH, Turkan I, Takio S (2007). Differential responses of antioxidative enzymes and lipid peroxidation to salt stress in salttolerant Plantago maritima and salt-sensitive Plantago media. Physiologia Plantarum 131(3):399-411.

Shao HB, Liang ZS, Shao MA (2005). Changes of some anti-oxidative enzymes under soil water deficits among 10 wheat genotypes at maturation stage. Colloids and Surfaces B: Biointerfaces 45:7-13.

Singh B, Usha K (2003). Salicylic acid induced physiological and biochemical changes in wheat seedlings under water stress. Journal of Plant Growth Regulation 39(2):137-141.

Stevens J, Senaratna T, Sivasithamparam K (2006). Salicylic acid induces salinity tolerance in tomato (Lycopersicon esculentum cv. Roma): associated changes in gas exchange, water relations and membrane stabilization. Plant Growth Regulation 49(1):77-83.

Szepesi A, Csiszar J, Bajkan S, Gemes K, Horvath V, Erdei L, Deer AK, Simon M, Tari I (2005). Role of salicylic acid pre-treatment on the acclimation of tomato plants to salt- and osmotic stress. Proceedings of the 8th Hungarian Congress on Plant Physiology and the 6th Hungarian Conference on Photosynthesis. Acta Biologica Szegediensis 49(1-2): 123-125.

Tanou G, Job C, Rajjou L, Arc E, Belghzi M, Diamantidis G, Molassiotis A, Job D (2009). Proteomics reveal the overlapping roles of hydrogen peroxide and nitric oxide in the acclimation of citrus plants to salinity. The Plant Journal 60(5):795-804.

Tari I, Csiszár J, Horváth E, Takács Z, Szepesi Á (2015). The alleviation of the adverse effects of salt stress in the tomato plant by salicylic acid shows a time- and organ-specific antioxidant response. Acta Biologica Cracoviensia Series Botanica 57(1):21-30.
Tari I, Csiszar J, Szalai G, Horvath F, Pecsvaradi A, Kiss G, Szepesi A, Szabo M, Erdei L (2002). Acclimation of tomato plants to salinity after a salicylic acid pre-treatment. Acta Biologica Szegediensis 46(34):55-56.

Tavakkoli E, Rengasamy P, McDonald GK (2010). High concentrations of $\mathrm{Na}^{+}$and $\mathrm{Cl}^{-}$ions in soil solution have simultaneous detrimental effects on growth of faba bean under salinity stress. Journal of Experimental Botany 61(15):4449-4459.

Türkan I, Demiral T (2009). Recent developments in understanding salinity tolerance. Environmental and Experimental Botany 67(1):2-9.

Vysotskaya L, Hedley PE, Sharipova G, Veselov D, Kudoyarova G, Morris J, Jones HG (2010). Effect of salinity on water relations of wild barley plants differing in salt tolerance. AoB Plants. doi: 10.1093/aobpla/plq006.

Yildirim E, Turan M, Guvenc I (2008). Effect of foliar salicylic acid applications on growth, chlorophyll and mineral content of cucumber (Cucumis sativus L.) grown under salt stress. Journal of Plant Nutrition 31:593-612.

Yu CW, Murphy TM, Lin CH (2003). Hydrogen peroxide-induced chilling tolerance in mung beans mediated through $\mathrm{ABA}$ independent glutathione accumulation. Functional Plant Biology 30:955-963.

Yusuf M, Fariduddin Q, Varshney P, Ahmad A (2012). Salicylic acid minimizes nickel and/or salinity-induced toxicity in Indian mustard (Brassica juncea) through an improved antioxidant system. Environmental Science and Pollution Research 19(1):8-18.

Yusuf M, Hasan SA, Ali B, Hayat S, Fariduddin Q, Ahmad A (2008). Effect of salicylic acid on salinity-induced changes in Brassica juncea. Journal of Integrated Plant Biology 50(9):1096-1102. 